\title{
(3) Loop L1 (odd level) type IIS cloning - pCk-ye vectors
}

\author{
Eftychis Frangedakis ${ }^{1}$, Susana Sauret-Gueto ${ }^{2}$, Anthony West $^{2}$, \\ Nicola Patron ${ }^{2}$, Marta Tomaselli ${ }^{3}$, Marius Rebmann², Jim Haseloff ${ }^{2}$ \\ ${ }^{1}$ University of Cambridge; \\ 2Plant Sciences, University of Cambridge, OpenPlant; \\ ${ }^{3}$ University of Cambridge, Open Plant
}

\section{OpenPlant Project}

\section{open ठAccess}

\section{Eftychis Frangedakis}

University of Cambridge, Plant Sciences

\section{DOI:}

dx.doi.org/10.17504/protocol s.io.4wegx be

Protocol Citation: Eftychis Frangedakis, Susana SauretGueto, Anthony West, Nicola Patron, Marta Tomaselli, Marius Rebmann, Jim Haseloff 2019. Loop L1 (odd level) type IIS cloning - pCk-ye vectors. protocols.io https://dx.doi.org/10.17504/p rotocols.io. 4 wegx be

License: This is an open access protocol distributed under the terms of the Creative Commons Attribution License, which permits unrestricted use, distribution, and reproduction in any medium, provided the original author and source are credited

Protocol status: Working We use this protocol and it's working

Created: Jun 28, 2019

Last Modified: Sep 24, 2019

Pollak B, Cerda A, Delmans M, et al (2019) Loop assembly: a simple and open system for recursive fabrication of DNA circuits. New Phytol 222:628-640

https://doi.org/10.1111/nph.15625

\section{MATERIALS}

\section{MATERIALS}

88 Bsal - 5,000 units New England Biolabs Catalog \#R0535L

88 T4 DNA Ligase - 20,000 units New England Biolabs Catalog \#M0202S

88 Sterile water Contributed by users

8 BSA, molecular biology grade, $20 \mathrm{mg} / \mathrm{ml}$ New England Biolabs Catalog \# B9000S

$\& 8$ 10X NEB T4 DNA ligase buffer New England Biolabs

PROTOCOL integer ID:

25254

1 Determine the concentrations of the DNA parts by spectrophotometry (Nanodrop). 
2 Prepare aliquots for DNA parts to be assembled at a concentration of $15 \mathrm{nM}$ and of the pCk vector at a concentration of $7.5 \mathrm{nM}$.

To calculate the concentration needed for each part to assemble (not the backbone) in $\mathrm{ng} / \mu \mathrm{L}$, divide the length of the plasmid where they are cloned by 100 . For the backbone, divide the plasmid length by 200 . In this way you can prepare aliquots of your parts and backbones and add $1 \mu \mathrm{L}$ of each one to the plasmid mix.

3 . Prepare Loop assembly Level 1 reaction master mix (MM) according to Table, if four or less number of parts are assembled into a pCk-pe vector.

\begin{tabular}{|c|c|}
\hline $\begin{array}{l}\text { Com } \\
\text { pone } \\
\text { nts }\end{array}$ & $\begin{array}{l}\text { Volu } \\
\text { me } \\
(\mu \mathrm{L})\end{array}$ \\
\hline $\begin{array}{l}\text { Steril } \\
\mathrm{e} \\
\text { water }\end{array}$ & 3 \\
\hline $\begin{array}{l}10 x \\
\text { T4 } \\
\text { ligase } \\
\text { buffer } \\
\text { (NEB) }\end{array}$ & 1 \\
\hline $\begin{array}{l}1 \\
\mathrm{mg} / \mathrm{m} \\
\mathrm{L} \\
\text { bovin } \\
\mathrm{e} \\
\text { seru } \\
\mathrm{m} \\
\text { album } \\
\text { in } \\
\text { (NEB) }\end{array}$ & 0.5 \\
\hline $\begin{array}{l}\text { T4 } \\
\text { DNA } \\
\text { ligase } \\
\text { at } 400 \\
\text { U/ } \mu \mathrm{L} \\
\text { (NEB) }\end{array}$ & 0.25 \\
\hline 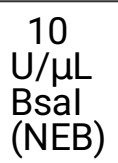 & 0.25 \\
\hline
\end{tabular}




\begin{tabular}{|l|l|}
\hline $\begin{array}{l}\text { Final } \\
\text { volum } \\
\text { e }\end{array}$ & 5 \\
\hline
\end{tabular}

4 Prepare plasmids mix for each reaction, by adding in a $0.2 \mathrm{~mL}$ tube, $1 \mu \mathrm{L}$ of each DNA part aliquot (see step 2), $1 \mu \mathrm{L}$ of the pCk-pe vector and sterile water up to $5 \mu \mathrm{L}$. Mix well.

5 Add $5 \mu \mathrm{L}$ of master mix to the $5 \mu \mathrm{L}$ of plasmids mix, to a final volume of $10 \mu \mathrm{L}$. Mix well. If more than 4 DNA parts are to be assembled into a pCk-pe vector, reduce the water volume in the MM by $1 \mu \mathrm{L}$ for each extra $1 \mu \mathrm{L}$ of DNA part added in the plasmids mix.

6 Place samples in a thermocycler and use the following program:

Assembly: 26 cycles of $37^{\circ} \mathrm{C}$ for $3 \mathrm{~min}$ and $16^{\circ} \mathrm{C}$ for $4 \mathrm{~min}$.

Termination and enzyme denaturation: $50^{\circ} \mathrm{C}$ for $5 \mathrm{~min}$ and $80^{\circ} \mathrm{C}$ for $10 \mathrm{~min}$.

7 Transform $20 \mu \mathrm{L}$ of chemically competent E. coli cells (transformation efficiency of $1 \times 107$ transformants/ $\mu$ g plasmid DNA) using $2 \mu \mathrm{L}$ of the Loop assembly reaction and then plate on LB agar plates containing $50 \mu \mathrm{g} / \mathrm{mL}$ kanamycin.

$8 \quad$ Incubate overnight at $37^{\circ} \mathrm{C}$.

9 Colonies with white color are likely to contain the vector with the insert while yellow color colonies will contain the empty vector.

10 Confirm the presence of the correct insert with Sanger sequencing using the primers pC_F and pC_R 
A
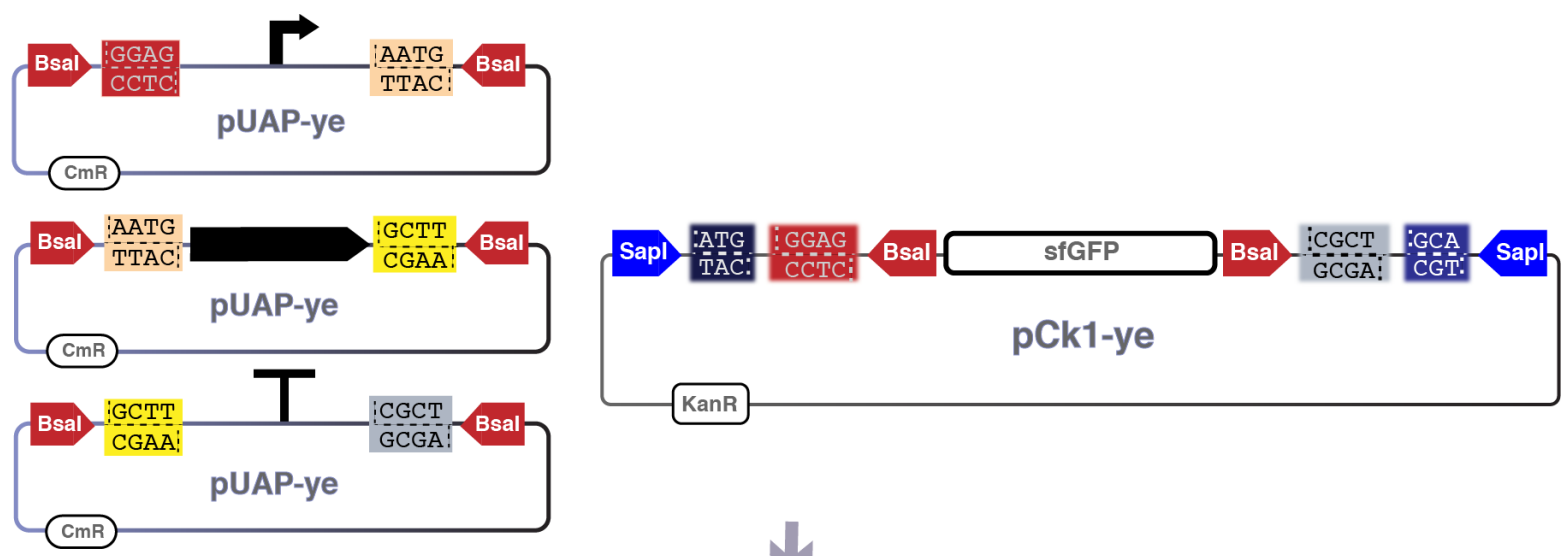

B

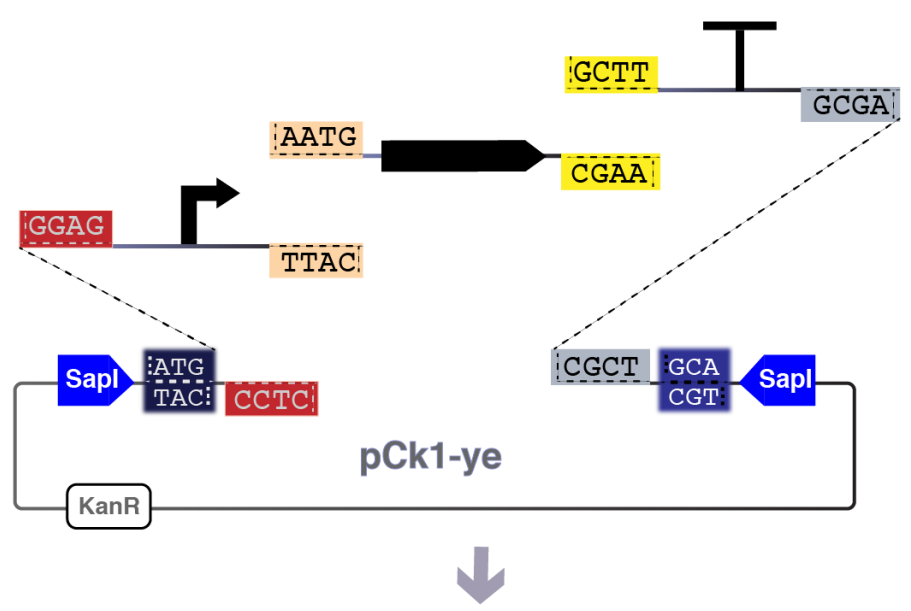

C

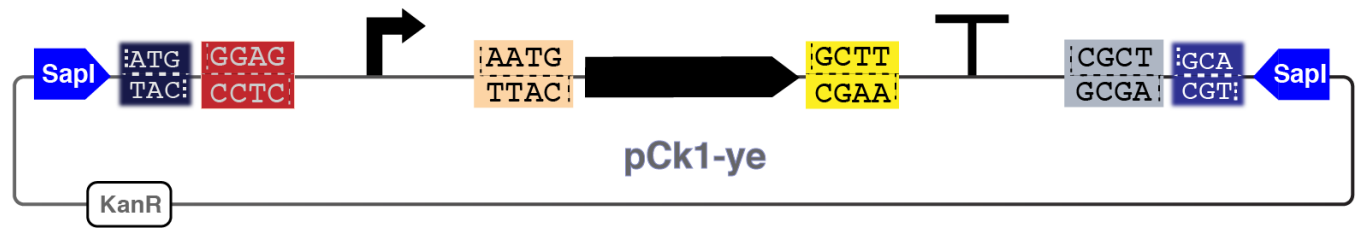


12
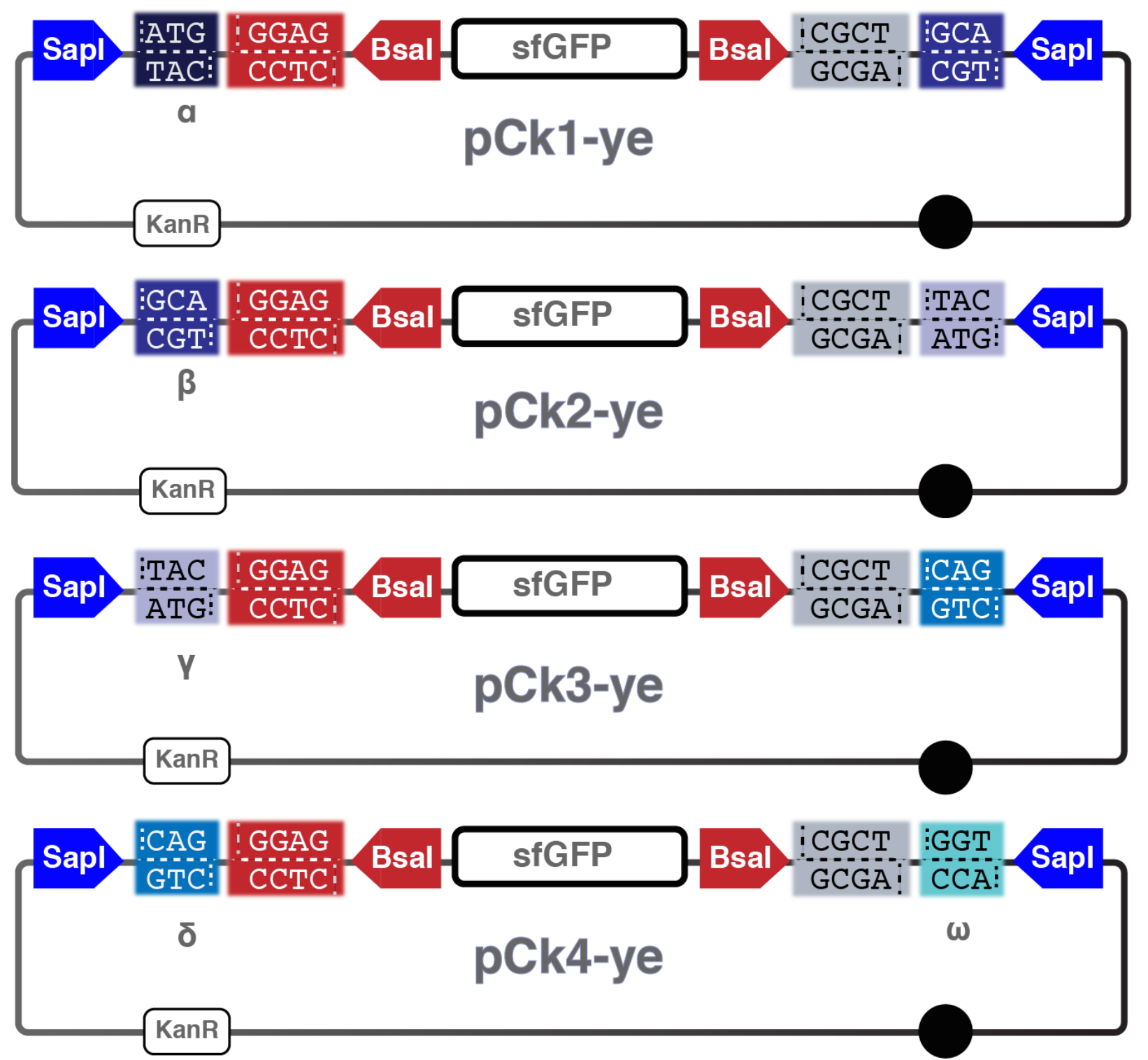